\title{
Covid-19 Pandemisinde Üniversite Öğrencilerindeki Oyun Bağımlılığı Düzeyleri ve Pandeminin Dijital Oyun Oynama Durumlarına Etkisi
}

\section{Game Addiction Levels of University Students in Covid-19 Pandemic and the Effect of Pandemic on Digital Gaming Status}

\author{
Berna Aktaş 1(D), Nihal Bostancı Daştan 1(iD \\ 1. Kafkas Üniversitesi Sağlık Bilimleri Fakültesi Psikiyatri Hemşireliği Anabilim Dalı, Kars, Türkiye
}

\section{Abstract}

Objective: This study aims to reveal the game addiction levels and the effect of the pandemic on digital gaming status in university students during the COVID-19 pandemic.

Method: The study sample was calculated as at least 384 individuals using the formula of sample for unknown population, and the study was completed online with 427 students. In the study, students were given an online Questionnaire and the Digital Game Addiction Scale for university students.

Results: Of the students, digital game play time was mostly $0-1$ hours before $(61.1 \%)$ and during $(52.5 \%)$ the pandemic, and $91.1 \%(n=389)$ was playing digital games on the phone during the pandemic. Students were mostly playing puzzles and mind games before (58.3\%) and during (56.0\%) the pandemic, and believing that their digital game play time (47.3\%) has not changed during the pandemic. The pandemic has increased the time spent on digital games and increased the play time on combat-strategy games. The average Digital Game Addiction Scale score of the university students was $35.86 \pm 16.97$. Moreover, $6.3 \%$ of the students was in the addicted group, and $1.6 \%$ was in the highly addicted group.

Conclusion: Comparison of the digital game play times of the students before and during the pandemic showed that this time increased significantly and most of them were on the mobile platform, and that the ratio of playing war-strategy games increased during the pandemic.

Keywords: Covid-19, university, student, game addiction

Öz

Amaç: Bu çalışmanın amacı COVID-19 pandemisinde üniversite öğrencilerindeki oyun bağımlıı̆ı düzeyleri ve pandeminin dijital oyun oynama durumlarına etkisinin belirlenmesidir.

Yöntem: Araştırmanın örneklemi; evreni bilinmeyen örneklem formülüyle en az 384 kişi olarak hesaplanmış, araştırma online olarak 427 öğrenci ile tamamlanmıştır. Araştırmada öğrencilere online olarak Anket Formu ve Üniversite Öğrencileri İçin Dijital Oyun Bağımlılığı Ölçeği uygulanmıştır.

Bulgular: Öğrencilerin pandemi öncesi (\%61.1) ve sürecinde (\%52.5) dijital oyun oynama süresinin 0-1 saat olarak yoğunlaştığı ve \%91.1'i $(n=389)$ pandemi sürecinde daha çok telefonla dijital oyun oynadığı görülmüştür. Öğrenciler pandemi öncesi (\%58.3) ve sürecinde (\%56.0) en çok bulmaca ve zeka oyunları oynamakta ve pandemi sürecinde dijital oyun oynama sürelerinin (\%47.3) değişmediğini düşünmektedir. Pandemi süreci öğrencilerin dijital oyun kullanım süresini ve savaş strateji oyunu oynamalarını arttırmıştır. Öğrencilerin Üniversite Öğrencileri İçin Dijital Oyun Bağımlılı̆ı Ölçeği puan ortalaması $35.86 \pm 16.97$ 'dir. Ayrıca öğrencilerin \%6.3'ü bağımlı grup ve \%1.6'sı yüksek düzeyde bağımlı grupta yer almaktadır.

Sonuç: Öğrencilerin pandemi öncesi ve pandemi sürecindeki dijital oyun oynama süreleri karşılaştıııldığında; bu sürenin pandemi sürecinde önemli düzeyde arttığı, pandemide en çok telefonla dijital oyun oynandığı ve pandemi sürecinin savaş-strateji oyunlarını oynama oranını artırdığı belirlenmiştir.

Anahtar kelimeler: Covid-19, üniversite, öğrenci, oyun bağımlılığı 


\section{Giriş}

Çin'in Hubei eyaletinin başkenti Wuhan'da Arallı 2019'da yetişkin bireyler nedeni bilinmeyen ciddi pnömoni nedeniyle hastanelere başvurmuş, koronavirüs (COVID-19), olarak adlandırılan bu salgın 31 Aralık 2019'da Dünya Sağlık Örgütü'ne (DSÖ) bildirilmiştir (1). COVID-19, 12 Mart 2020 itibariyle DSÖ tarafından, küresel bir salgın olarak duyurulmuş (2) ülkemizde ise ilk vaka 11 Mart 2020'de tespit edilmiştir (3). COVID-19'un etkisiyle hükümetler hastalığın yayılmasını engellemek için (2) arasında okulların kapatıması $(4,5)$, ev tabanlı uzaktan öğrenme modellerinin kullanılması (5), açık alanlara girişlerin yasaklanması, çalışma rutinlerinin değişmesi (6) ve zorunlu "sosyal mesafe" nedeniyle yüz yüze etkileşimlerin sınırlandıııması (2) gibi bir dizi önlem almıştır. İnsanoğlu doğası gereği birlikte yaşama ve organize gruplar olarak işlev görmeye alıştığından (7), sosyal izolasyon önlemleri insanlarda çeşitli ruhsal zorlukların ortaya çıkmasına neden olmuştur (8). Önlemler nedeniyle evde kalan birçok bireyde internet, teknoloji kullanımı (8) ve dijital oyunları oynama oranı (9) büyük oranda artmıştır.

Davranışsal bir bağımlılık olarak nitelendirilen dijital oyun bağımlıı̆̆; bireyin dijital oyunları oynama isteğini kontrol edemediği, duygu, düşünce, davranışlarında ve günlük yaşamında dijital oyun oynama kaynaklı çeşitli değişim ve bozulmaların olduğu bir durumdur $(10,11)$. Dijital oyun bağımlılı̆ının temelde ödül eksikliği ile ilişkili olduğu ve bu noktada mezokortikolimbik yolak ve dopaminin önemli bir rolünün olduğuna işaret edilmektedir (10). Bağımlı olan bireylerde beyinde haz ve ödül sistemlerinden sorumlu dopaminin üretimi artışı ve dopamin alııılarının yetersiz kalması kişiyi bağımlı olunan madde/davranışa yöneltir (12). Psikoaktif madde kullanımı, kumar, video oyunları oynama, sosyal medyayı kullanma, pornografi izleme veya internette gezinme gibi potansiyel olarak bağımlıık yapıcı davranışlar genellikle stresi, endişeyi azaltmada ve / veya depresif ruh halini hafifletmede ve günlük yaşamın sorunlarından/ zor düşüncelerden kaçınmada yardımcı olabilir. COVID-19 pandemisi gibi krizlerde başa çıkma stratejisi olarak bu davranışlara girişme eğilimi önemli ölçüde artarak zararlı alışkanlıklara dönüşebilir $(9,13)$.

Ingiltere merkezli global sosyal medya ajansı We Are Social ve sosyal medya depolama aracı olan Hootsuit'in ortak yayınladığı Nisan 2020 Dijital Raporuna göre COVID-19 salgınında bilgisayar veya video oyunları oynamak için \% 35 daha fazla zaman harcanmaktadır. Ayrıca bilgisayar veya video oyunları oynama davranışının salgın sona erdikten sonra bile \%10 oranında yeni davranış olarak devam etmesi beklenmektedir (14). DSÖ'ye göre, sosyal izolasyon sürecinde video oyunları rahatlamanın bir yolu olsa da, oyunlarla normalden uzun süre zaman geçirmek cazip gelebilir (15) ve bununla birlikte özellikle gençler için yeni davranışsal bağımlııklar ortaya çıkabilir (7).

Anadolu Üniversitesi Sosyal Medya ve Dijital Güvenlik Eğitim Uygulama ve Araştırma Merkezi (SODiGEM) araştırmacılarının yaptığı bir anket sonucuna göre, COVID-19 döneminde bireylerin dijital ortamda ve cep telefonlarıyla geçirdikleri süre büyük oranda artmış ve evde geçirilen süre içinde dijital oyun oynama sıklı̆ı̆ındaki en büyük artış 18-24 yaş grubundaki bireylerde saptanmıştır (16). Öte yandan, bu yaş döneminde olan üniversite öğrencileri daha bağımsız bir yaşam sürmeleri, akıllı telefon, tablet, bilgisayar gibi çeşitli oyun araçları ve internete kolay erişmeleri gibi nedenlerle dijital oyunlarla daha fazla zaman geçirmektedir (17). Bu yönden bakıldığında bu çalışmanın dijital oyun kullanımının bağımılık boyutuna ulaşmasında COVID- 19 salgın döneminde üniversite öğrencilerindeki oyun bağımlılı̆̆ düzeyleri, dijital oyun oynama durumlarını ve salgının bu durumlardaki etkisini ortaya çıkararak literatüre katkı sağlayacağı düşünülmektedir. Bu araştırmanın amacı COVID-19 pandemisinde üniversite öğrencilerindeki oyun bağımlı̆̆ı düzeyleri ve pandeminin dijital oyun oynama durumlarına etkisinin belirlenmesidir.

\section{Yöntem}

\section{Örneklem}

Bu araştırma kesitsel tipte bir çalışmadır. Araştırmada "COVID-19 pandemi sürecinde üniversite öğrencilerinin dijital oyun bağımlılık düzeyleri nedir?, COVID-19 pandemi sürecinde üniversite öğrencilerinin 
dijital oyun oynama özellikleri nedir?, Üniversite öğrencilerinde COVID-19 pandemi sürecinde oyun oynama özelliklerini etkileyen faktörler nelerdir? ve COVID-19 pandemi öncesi ve sürecinde dijital oyun oynama süresine yönelik farklılıklar nelerdir?" sorularının cevabı arandı. Araşıımanın örneklemi; evreni bilinmeyen örneklem hesabı kullanılarak $n=p^{*} q^{\star} t 2 / d 2$ formülüyle hesaplandı. Literatürde üniversite öğrencilerinin tümünü içeren bir dijital oyun kullanımı sıklığı görülmediği için p ve q değerleri 0.50, 050; t değeri 1.96 ve d (kabul edilen örneklem hatası) değeri 0.05 alındığında örneklem en az 384 kişi olarak hesaplandı (18). Araştırma online olarak ulaşılan 427 öğrenci ile tamamlandı. Çalışmaya dâhil edilme kriterleri; a) üniversite öğrencisi olma, b) çalışmaya katımaya gönüllü olma, c) dijital olarak oyun oynama iken çalışmadan dışlanma kriteri dijital oyun oynamamadır.

\section{İşlem}

Araştırma için Kafkas Üniversitesi Sağlık Bilimleri Fakültesi Girişimsel Olmayan Araştırmalar Etik Kurul Başkanlığı'ndan (08/06/2020 tarih ve 81829502.903/42 sayılı) izin alındı. Araştırmada kullanılan ölçüm aracını geliştiren kişilerden e-mail aracılığıyla izin alındıktan sonra araştırmaya katılan öğrencilere online anket doldurma sürecinde araştırmanın amacı yazılarak onamları alındı. Araştırmada öğrencilere pandemi sürecinde 08 Haziran 2020- 30 Temmuz 2020 tarihleri arasında çevrimiçi olarak Google Formlar yöntemi ile Anket Formu ve Üniversite Öğrencileri İçin Dijital Oyun Bağımlı̆ı̆ı Öıçeği uygulandı. Çalışma evrenine ulaşılmadan önce 10 öğrenci ile veri formlarına ulaşım ve anlaşııma yönünde pilot çalışma yapıldı.

\section{Veri Toplama Araçları}

\section{Anket Formu}

Anket Formu araştırmacılar tarafından ilgili literatür taranarak $(7,9,14,16,17)$ cinsiyet, yaş gibi sosyodemografik özellikler ve dijital oyun oynama özelliklerinden oluşan 12 soruluk bir formdur.

\section{Üniversite Öğrencileri İ̧in Dijital Oyun Bağımlılığı Ölçeği}

Uyarlama çalışması Hazar ve Hazar tarafından (17) yapılan ölçekteki ifadelerin değerlendirilmesinde 5 puanlı Likert tipi öz bildirim yönteminden yararlanılmıştır (1= Kesinlikle Katılmıyorum, $5=$ Tamamen Katılıyorum). Ölçekten alınabilecek en düşük puan "21" en yüksek puan "105" tir. Ölçek puanlamasının derecelendirmesinde ise; "1-21 puan: Normal grup, 22-42 puan: Az riskli grup, 43-63 puan: Riskli grup, 64-84 puan: Bağımlı grup ve 85-105 puan: Yüksek düzeyde bağımlı grup" olarak değerlendirilmektedir. Hazar ve Hazar'ın (17) çalışmasında ve çalışmamızda Cronbach alfa kat sayısı 0.95 olarak bulunmuştur.

\section{Veri Analizi}

Çalışmada elde edilen niceliksel veriler SPSS 20.0 programında değerlendirildi ve istatistik analizler için; tanımlayıcı istatistiksel metodlar (ortalama, sayı, yüzdelik), pandemi sürecinde dijital oyun oynama özelliklerini etkileyen faktörleri belirlemede Ki-Kare analizi, pandemi öncesi ve süreci dijital oyun oynama süreci farkılıklarını belirlemede tekrarlı ölçümlerde t testi kullanıldı. $p<0.05$ değeri istatistiksel olarak anlamlı kabul edildi.

\section{Bulgular}

Öğrencilerin tanıtıcı özellikleri incelendiğinde \%69.1'inin ( $n=295)$ kız, \%49.2'sinin ( $n=210)$ 21-24 yaş arası, \%93.4'ünün ( $n=399)$ bağımlıık yapıcı herhangi bir alışkanlığı olmadığı, bağımlıık yapıcı alışkanlığı olan öğrencilerin \%4'ünün $(n=17)$ sigara alışkanlığının olduğu, \%64.4'ünün $(n=275)$ evinde internet bulunduğu belirlendi (Tablo 1).

Öğrencilerin pandemi sürecinde \%91.1'inin telefon ile dijital oyun oynadığı, pandemi öncesi (\%61.1) ve sürecinde (\%52.5) dijital oyun oynama süresi 0-1 saat olarak yoğunlaştığı bulundu. Öğrencilerin pandemi öncesi (\%58.3) ve süreci (\%56.0) en çok oynadığı dijital oyunun bulmaca ve zeka oyunları olduğu, \%47.3'ünün pandemi sürecinde dijital oyun oynama sürelerinin değişmediğini düşündüğü belirlendi (Tablo 2). 
Tablo 1. Öğrencilerin tanıtıcı özellikleri $(\mathrm{n}=427)$

\begin{tabular}{|c|c|c|}
\hline Özellikler & $\mathrm{n}$ & $\%$ \\
\hline \multicolumn{3}{|l|}{ Cinsiyet } \\
\hline KIZ & 295 & 69.1 \\
\hline Erkek & 132 & 30.9 \\
\hline \multicolumn{3}{|l|}{ Yaş } \\
\hline 20 ve altı & 168 & 39.3 \\
\hline $21-24$ & 210 & 49.2 \\
\hline 25 ve üzeri & 49 & 11.5 \\
\hline \multicolumn{3}{|c|}{ Bağımlılık yapıcı herhangi bir alışkanlığı olma durumu } \\
\hline Evet & 28 & 6.6 \\
\hline Hayır & 399 & 93.4 \\
\hline \multicolumn{3}{|c|}{ Bağımlılık yapıcı alışkanlıklar } \\
\hline Yok & 399 & 93.4 \\
\hline Sigara & 17 & 4.0 \\
\hline Oyun & 6 & 1.4 \\
\hline Cep Telefonu & 4 & 0.9 \\
\hline Sosyal Medya & 1 & 0.3 \\
\hline \multicolumn{3}{|c|}{ Evde internet bulunma durumu } \\
\hline Evet & 275 & 64.4 \\
\hline Hayır & 152 & 35.6 \\
\hline
\end{tabular}

Öğrencilerin Dijital Oyun Bağımlı̆ı̆ı Ölçeği puanlarına göre bağımlılık düzeyleri incelendiğinde puan ortalamasının $35.86 \pm 16.97$ (Minimum Puan: 21.00; Maksimum Puan: 105.00) olduğu görüldü. Ayrıca öğrencilerin \%12.9'unun normal grup, \%61.8'inin az riskli grup, \%17.3'ünün riskli grup, \% 6.3'ünün bağımlı grup ve \%1.6'sının yüksek düzeyde bağımlı grupta yer aldığı belirlendi.

Öğrencilerin cinsiyetlerine göre COVID-19 pandemi süresince dijital oyun oynama özelliklerinin karşısştııımasına bakıldığında (Tablo 3); Dijital oyun oynamak için en çok kullanılan araç açısından anlamlı farklılık olduğu (X2=24.956; $p<0.001)$; kı öğrencilerin en çok telefonu (\%94.8), erkek öğrencilerin telefonun (\%82.5) yanı sıra bilgisayarı da (\%15.2) tercih ettikleri görüldü. Tercih edilen dijital oyun türü açısından anlamlı farklılık olduğu $(X 2=98.721 ; p<0.001)$; kız öğrencilerin en çok bulmaca ve zeka oyunlarını (\%71.2), erkek öğrencilerin savaş ve strateji oyunlarını (\%52.2) tercih ettikleri görüldü. Dijital oyunlarla geçirilen zaman açısından anlamlı farklılık olduğu ( $X 2=34.764 ; 0<0.001)$; kız öğrencilerin en çok 0-1 saat arası (\%60.3), erkek öğrencilerin 3 saatten fazla oyun zaman diliminin kızlara göre yüksek olduğu görüldü. COVID-19 pandemisinde dijital oyun oynama süresinde değişim açısından anlamlı farkkılık olduğu $(X 2=22.063 ; \quad p<0.001)$; kız öğrencilerin dijital oyun oynama süresinin azaldığını (\%54.2), erkek öğrencilerin ise arttığını düşündüğü (\%53.0) görüldü.

Öğrencilerin bağımlılık yapıcı herhangi bir alışkanlığı olma durumuna göre COVID-19 pandemi süresince dijital oyun oynama özelliklerinin karşılaştııımasına bakıldığında (Tablo 4); dijital oyun oynamak için en çok kullanılan araç açısından istatistiksel olarak anlamlı farklıık olmadığı görüldü ( $p>0.05$ ). Tercih edilen dijital oyun türü açısından anlamlı bir farklılık olduğu (X2=20.954; $p<0.001)$; bağımlılık yapıcı herhangi bir alışkanlığı olanların en çok savaş ve strateji (\%38.9), olmayanların ise bulmaca ve zeka (\%59.1) oyunlarını tercih ettikleri görüldü. Dijital oyunlarla geçirilen zaman açısından anlamlı bir farklılık olduğu $(X 2=14.880$; p<0.05); bağımlılık yapıcı herhangi bir alışkanlığı olanların 4 saatten fazla (\%27.8) dijital oyun oynadıkları görülürken, bağımlıık yapıcı herhangi bir alışkanlığı olmayanlarda ise 4 saatten fazla oyun oynama süresinin (\%13.0) çok daha az olduğu görüldü. COVID-19 pandemisinde dijital oyun oynama süresinde değişim açısından anlamlı bir farklıık olduğu $(X 2=8.967 ; p<0.05)$; bağımlıık yapıcı herhangi bir alışkanlığı olanlar dijital oyun oynama sürelerinin artıığını (\%58.4) düşünürken bağımlılık yapıcı herhangi bir alışkanlığı olmayanların dijital oyun oynama sürelerinin değişmediğini (\%49.4) düşündüğü görüldü.

Öğrencilerin evlerinde internet bağlantısı olma durumlarına göre COVID-19 pandemi süresince dijital oyun oynama özelliklerinin karşılaştırımasına bakıldığında (Tablo 5); dijital oyun oynamak için en çok kullanılan 
araç açısından anlamlı bir farklılık olduğu $(X 2=20.645 ; p<0.001)$; evlerinde internet bağlantısı olanların telefonun (\%86.9) yanı sıra bilgisayar (\%10.6) ve oyun konsolunu (\%1.8) tercih ettikleri görülürken evlerinde internet bağlantısı olmayanların en çok telefonu (\%98.7) tercih ettikleri görüldü. Tercih edilen oyun türü açısından anlamlı bir farklıık olduğu $(X 2=10.788 ; p<0.05)$; evlerinde internet bağlantısı olanların sıkıkla bulmaca ve zeka oyunlarının (\%51.3) yanı sıra savaş ve strateji oyunlarını (\%30.5), evlerinde internet bağlantısı olmayanlar ise bulmaca ve zeka oyunlarını (\%64.5) tercih ettikleri görüldü. Dijital oyunlarla geçirilen zaman açısından anlamlı bir farklılık olduğu $(X 2=14.859 ; p<0.05)$; evlerinde internet bağlantısı olanların (\%17.8) 4 saatten fazla oyun oynama sürelerinin internet bağlantısı olmayanlardan (\%7.9) daha fazla olduğu görüldü. COVID-19 pandemisinde dijital oyun oynama süresinde değişim açısından anlamlı bir farklıık olduğu $(X 2=16.337 ; p<0.001)$; evlerinde internet bağlantısı olanların (\%42.9) evlerinde internet bağlantısı olmayanlara (\%27.6) oranla dijital oyun kullanımının daha fazla arttığını düşündükleri görüldü.

Tablo 2. Öğrencilerin pandemi öncesi ve sürecinde dijital oyun oynama özellikleri $(n=427)$

\begin{tabular}{|c|c|c|}
\hline \multirow{2}{*}{\multicolumn{3}{|c|}{$\begin{array}{l}\text { Oyun Oynama Özellikleri } \\
\text { Pandemi sürecinde dijital oyun oynamak için kullanılan araç }\end{array}$}} \\
\hline & & \\
\hline Bilgisayar & 29 & 6.8 \\
\hline Oyun konsolu & 5 & 1.2 \\
\hline Telefon & 389 & 91.1 \\
\hline Tablet & 4 & 0.9 \\
\hline \multicolumn{3}{|c|}{ Pandemi öncesi dijital oyunlarla geçirilen zaman } \\
\hline $0-1$ saat & 261 & 61.1 \\
\hline $1-2$ saat & 76 & 17.8 \\
\hline 2-3 saat & 38 & 8.9 \\
\hline 3-4 saat & 21 & 4.9 \\
\hline 4 saatten fazla & 31 & 7.3 \\
\hline \multicolumn{3}{|c|}{ Pandemi sürecinde dijital oyunlarla geçirilen zaman } \\
\hline $0-1$ saat & 224 & 52.5 \\
\hline 1-2 saat & 69 & 16.2 \\
\hline 2-3 saat & 41 & 9.6 \\
\hline 3-4 saat & 32 & 7.5 \\
\hline 4 saatten fazla & 61 & 14.3 \\
\hline \multicolumn{3}{|c|}{ Pandemi öncesi en çok oynanan dijital oyun türü } \\
\hline Macera oyunları & 37 & 8.7 \\
\hline Spor ve yarış oyunları & 43 & 10.1 \\
\hline Savaş ve strateji oyunları & 98 & 23.0 \\
\hline Bulmaca ve zekâ oyunları & 249 & 58.3 \\
\hline \multicolumn{3}{|c|}{ Pandemi sürecinde en çok oynanan dijital oyun türü } \\
\hline Macera oyunları & 37 & 8.7 \\
\hline Spor ve yarış oyunları & 42 & 9.8 \\
\hline Savaş ve strateji oyunları & 109 & 25.5 \\
\hline Bulmaca ve zekâ oyunları & 239 & 56.0 \\
\hline \multicolumn{3}{|c|}{ Pandemi sürecinde dijital oyun oynama süresinde değişme durumu } \\
\hline Arttı & 160 & 37.5 \\
\hline Azaldı & 38 & 8.9 \\
\hline Değişmedi & 202 & 47.3 \\
\hline Fikrim yok & 27 & 6.3 \\
\hline
\end{tabular}

Öğrencilerin COVID-19 pandemi öncesi ve pandemi sürecinde dijital oyun oynama sürelerinin karşılaş̧ıııımasına bakıldığında (Tablo 6); pandemi sürecinde dijital oyunlarla geçirilen zamanda istatistiksel olarak anlamlı farklılık yaratacak şekilde artma olduğu görüldü ( $t=6.098 ; p<0.001)$. 
Tablo 3. Öğrencilerin cinsiyetlerine göre COVID-19 pandemi süresince dijital oyun oynama özelliklerinin karşılaştırılması $(n=427)$

\begin{tabular}{|c|c|c|c|c|c|c|c|}
\hline \multirow{3}{*}{$\begin{array}{l}\text { Dijital Oyun Oynama } \\
\text { Özellikleri }\end{array}$} & \multicolumn{6}{|c|}{ Cinsiyet } & \multirow{3}{*}{$X^{2} ; p$} \\
\hline & \multicolumn{2}{|c|}{ KIZ } & \multicolumn{2}{|c|}{ Erkek } & \multicolumn{2}{|c|}{ Toplam } & \\
\hline & $\mathrm{n}$ & $\%$ & $\mathrm{n}$ & $\%$ & $\mathrm{n}$ & $\%$ & \\
\hline \multicolumn{8}{|c|}{ Dijital oyun oynamak için en çok kullanılan araç } \\
\hline Bilgisayar & 9 & 3.1 & 20 & 15.2 & 29 & 6.8 & \multirow{4}{*}{$\begin{array}{l}X^{2}=24.956 \\
p<0.001\end{array}$} \\
\hline Oyun konsolu & 2 & 0.7 & 3 & 2.3 & 5 & 1.2 & \\
\hline Telefon & 280 & 94.8 & 109 & 82.5 & 389 & 91.1 & \\
\hline Tablet & 4 & 1.4 & 0 & 0.0 & 4 & 0.9 & \\
\hline \multicolumn{8}{|c|}{ Dijital oyunda tercih edilen oyun türü } \\
\hline Macera oyunları & 20 & 6.8 & 17 & 12.9 & 37 & 8.7 & \multirow{4}{*}{$\begin{array}{c}X^{2}=98.721 \\
p<0.001\end{array}$} \\
\hline Spor ve yarış oyunları & 25 & 8.5 & 17 & 12.9 & 42 & 9.8 & \\
\hline Savaş ve strateji oyunları & 40 & 13.5 & 69 & 52.2 & 109 & 25.5 & \\
\hline Bulmaca ve zekâ oyunları & 210 & 71.2 & 29 & 22.0 & 239 & 56.0 & \\
\hline \multicolumn{8}{|c|}{ Dijital oyunlarla geçirilen zaman } \\
\hline $0-1$ saat & 178 & 60.3 & 46 & 34.8 & 224 & 52.5 & \multirow{5}{*}{$\begin{array}{c}X^{2}=34.764 \\
p<0.001\end{array}$} \\
\hline $1-2$ saat & 43 & 14.6 & 26 & 19.7 & 69 & 16.2 & \\
\hline 2-3 saat & 30 & 10.2 & 11 & 8.3 & 41 & 9.6 & \\
\hline 3-4 saat & 13 & 4.4 & 19 & 14.4 & 32 & 7.4 & \\
\hline 4 saatten fazla & 31 & 10.5 & 30 & 22.8 & 61 & 14.3 & \\
\hline \multicolumn{8}{|c|}{ Dijital oyun oynama süresinde değişim } \\
\hline Arttı & 90 & 30.5 & 70 & 53.0 & 160 & 37.5 & \multirow{4}{*}{$\begin{array}{c}X^{2}=22.063 \\
p<0.001\end{array}$} \\
\hline Değişmedi & 26 & 8.8 & 12 & 9.1 & 38 & 8.9 & \\
\hline Azaldı & 160 & 54.2 & 42 & 31.8 & 202 & 47.3 & \\
\hline Fikrim yok & 19 & 6.5 & 8 & 6.1 & 27 & 6.3 & \\
\hline
\end{tabular}

Tablo 4. Öğrencilerin bağımlılık yapıcı herhangi bir alışkanlığı olma durumuna göre Covid-19 pandemi süresince dijital oyun oynama özelliklerinin karşılaştırılması $(n=427)$

\begin{tabular}{|c|c|c|c|c|c|c|c|}
\hline \multirow{3}{*}{$\begin{array}{l}\text { Difittal Oyun Oynama } \\
\text { Ozzellikleri }\end{array}$} & \multicolumn{6}{|c|}{ Bağımlılık Yapıcı Alışkanlık } & \multirow{3}{*}{$X^{2} ; p$} \\
\hline & \multicolumn{2}{|c|}{ Evet } & \multicolumn{2}{|c|}{ Hayır } & \multicolumn{2}{|c|}{ Toplam } & \\
\hline & $\mathrm{n}$ & $\%$ & $\mathrm{n}$ & $\%$ & $\mathrm{n}$ & $\%$ & \\
\hline \multicolumn{8}{|c|}{ Dijital oyun oynamak için en çok kullanılan araç } \\
\hline Bilgisayar & 6 & 16.7 & 23 & 5.9 & 29 & 6.8 & \multirow{4}{*}{$\begin{array}{c}X^{2}=6.734 \\
p>0.05\end{array}$} \\
\hline Oyun konsolu & 0 & 0.0 & 5 & 1.3 & 5 & 1.2 & \\
\hline Telefon & 30 & 83.3 & 359 & 91.8 & 389 & 91.1 & \\
\hline Tablet & 0 & 0.0 & 4 & 1.0 & 4 & 0.9 & \\
\hline \multicolumn{8}{|c|}{ Dijital oyunda tercih edilen oyun türü } \\
\hline Macera oyunları & 8 & 22.2 & 29 & 7.4 & 37 & 8.7 & \multirow{4}{*}{$\begin{array}{c}X^{2}=20.954 \\
p<0.001\end{array}$} \\
\hline Spor ve yarış oyunları & 6 & 16.7 & 36 & 9.2 & 42 & 9.8 & \\
\hline Savaş ve strateji oyunları & 14 & 38.9 & 95 & 24.3 & 109 & 25.5 & \\
\hline Bulmaca ve zekâ oyunları & 8 & 22.2 & 231 & 59.1 & 239 & 56.0 & \\
\hline \multicolumn{8}{|c|}{ Dijital oyunlarla geçirdiğiniz zaman } \\
\hline $0-1$ saat & 10 & 27.8 & 214 & 54.8 & 224 & 52.5 & \multirow{5}{*}{$\begin{array}{c}X^{2}=14.880 \\
p<0.05\end{array}$} \\
\hline $1-2$ saat & 11 & 30.6 & 58 & 14.8 & 69 & 16.2 & \\
\hline 2-3 saat & 3 & 8.3 & 38 & 9.7 & 41 & 9.5 & \\
\hline $3-4$ saat & 2 & 5.5 & 3 & 7.7 & 32 & 7.5 & \\
\hline 4 saatten fazla & 10 & 27.8 & 51 & 13.0 & 61 & 14.3 & \\
\hline \multicolumn{8}{|c|}{ Dijital oyun oynama süresinde değişim } \\
\hline Arttı & 21 & 58.4 & 139 & 35.5 & 160 & 37.5 & \multirow{4}{*}{$\begin{array}{c}X^{2}=8.967 \\
p<0.05\end{array}$} \\
\hline Azaldı & 3 & 8.3 & 35 & 9.0 & 38 & 8.9 & \\
\hline Değişmedi & 9 & 25.0 & 193 & 49.4 & 202 & 47.3 & \\
\hline Fikrim yok & 3 & 8.3 & 24 & 6.1 & 27 & 6.3 & \\
\hline
\end{tabular}


Tablo 5. Öğrencilerin evlerinde internet bağlantısı durumuna göre Covid-19 pandemi süresince dijital oyun oynama özelliklerinin karşılaştırıması $(n=427)$

\begin{tabular}{|c|c|c|c|c|c|c|c|}
\hline \multirow{3}{*}{$\begin{array}{l}\text { Dijital Oyun Oynama } \\
\text { Özellikleri }\end{array}$} & \multicolumn{6}{|c|}{ Evde İnternet Bağlantısı Durumu } & \multirow{3}{*}{$X^{2} ; p$} \\
\hline & \multicolumn{2}{|c|}{ Evet } & \multicolumn{2}{|c|}{ Hayır } & \multicolumn{2}{|c|}{ Toplam } & \\
\hline & $\mathrm{n}$ & $\%$ & $\mathrm{n}$ & $\%$ & $\mathrm{n}$ & $\%$ & \\
\hline \multicolumn{8}{|c|}{ Dijital oyun oynamak için en çok kullanılan araç } \\
\hline Bilgisayar & 29 & 10.6 & 0 & 0.0 & 29 & 6.8 & \multirow{4}{*}{$\begin{array}{c}X^{2}=20.645 \\
p<0.001\end{array}$} \\
\hline Oyun konsolu & 5 & 1.8 & 0 & 0.0 & 5 & 1.2 & \\
\hline Telefon & 239 & 86.9 & 150 & 98.7 & 389 & 91.1 & \\
\hline Tablet & 2 & 0.7 & 2 & 1.3 & 4 & 0.9 & \\
\hline \multicolumn{8}{|c|}{ Dijital oyunda tercih edilen oyun türü } \\
\hline Macera oyunları & 24 & 8.7 & 13 & 8.6 & 37 & 8.7 & \multirow{4}{*}{$\begin{aligned} X^{2} & =10.788 \\
p & <0.05\end{aligned}$} \\
\hline Spor ve yarış oyunları & 26 & 9.5 & 16 & 10.5 & 42 & 9.8 & \\
\hline $\begin{array}{l}\text { Savaş ve strateji } \\
\text { oyunları }\end{array}$ & 84 & 30.5 & 25 & 16.4 & 109 & 25.5 & \\
\hline $\begin{array}{l}\text { Bulmaca ve zekâ } \\
\text { oyunları }\end{array}$ & 141 & 51.3 & 98 & 64.5 & 239 & 56.0 & \\
\hline \multicolumn{8}{|c|}{ Dijital oyunlarla geçirdiğiniz zaman } \\
\hline $0-1$ saat & 127 & 46.2 & 97 & 63.8 & 224 & 52.5 & \multirow{5}{*}{$\begin{array}{c}X^{2}=14.859 \\
p<0.05\end{array}$} \\
\hline $1-2$ saat & 46 & 16.7 & 23 & 15.2 & 69 & 16.1 & \\
\hline 2-3 saat & 30 & 10.9 & 11 & 7.2 & 41 & 9.6 & \\
\hline 3-4 saat & 23 & 8.4 & 9 & 5.9 & 32 & 7.5 & \\
\hline 4 saatten fazla & 49 & 17.8 & 12 & 7.9 & 61 & 14.3 & \\
\hline \multicolumn{8}{|c|}{ Dijital oyun oynama süresinde değişim } \\
\hline Arttı & 118 & 42.9 & 42 & 27.6 & 160 & 37.5 & \multirow{4}{*}{$\begin{array}{c}X^{2}=16.337 \\
p<0.001\end{array}$} \\
\hline Azaldı & 19 & 6.9 & 19 & 12.5 & 38 & 8.9 & \\
\hline Değişmedi & 127 & 46.2 & 75 & 49.4 & 202 & 47.3 & \\
\hline Fikrim vok & 11 & 4.0 & 16 & 10.5 & 27 & 6.3 & \\
\hline
\end{tabular}

Tablo 6. Öğrencilerin Covid-19 pandemi öncesi ve süresinde dijital oyun oynama sürelerinin karşılaşıııııması $(n=427)$

\begin{tabular}{|l|c|c|}
\hline Süre & Ort. $\pm S . S$. & $\mathrm{t} ; \mathrm{p}$ \\
\hline Pandemisi öncesi dijital oyunlarla geçirilen zaman & $1.79 \pm 1.22$ & $\mathrm{t}=-6.098$ \\
\hline Pandemi sürecinde dijital oyunlarla geçirilen zaman & $2.15 \pm 1.47$ & $\mathrm{p}<0.001$ \\
\hline
\end{tabular}

\section{Tartışma}

Çalışmamızda; Üniversite Öğrencileri İçin Dijital Oyun Bağımlıı̆ı Ölçeği 'ne öğrencilerin \%6.3'ünün bağımlı grup ve \%1.6'sının yüksek düzeyde bağımlı grupta yer aldığı belirlendi. Bülbül ve arkadaşlarının (19) çalışmasında öğrencilerin \%21'inin, Koç'un (20) çalışmasında \%5.1'inin, Miezaha ve arkadaşlarının (21) çalışmasında \%12.2'sinin, Li ve arkadaşlarının (22) çalışmasında ise \%4.7'sinin oyun bağımlısı olduğu belirlenmiştir. Dijital oyun bağımlıı̆ına yönelik bu epidemiyolojik farklılıklar; oyun oynama nedenlerindeki kültürel çeşitlilikten, araştırmaların yapıldığı popülasyonun, zaman diliminin ve kullanılan ölçüm araçlarının özelliklerinden kaynaklanabilir.

Çalışmamızda kız öğrencilerin oyun oynamak için en çok telefonu (\%94.8) erkek öğrencilerin ise telefonun (\%82.5) yanı sıra bilgisayarı da (\%15.2) tercih ettikleri, kız öğrencilerin en çok bulmaca ve zeka oyunlarını (\%71.2), erkek öğrencilerin ise savaş ve strateji oyunlarını (\%52.2) tercih ettikleri, kız öğrenciler dijital oyunlarla en çok 0-1 saat arası (\%60.3) zaman geçirirken erkek öğrencilerin dijital oyunlarla geçirdikleri zaman diliminin kızlara göre yüksek olduğu, kız öğrencilerin COVID-19 sürecinde dijital oyun oynama süresinin azaldığı (\%54.2), erkek öğrencilerin ise arttığı (\%53.0) görüldü. Lee ve Kim'in (23) Koreli ergenlerle yaptıkları bir çalışmada bilgisayarda dijital oyun oynama süresinin erkeklerin bağımlılık eğilimini, 
telefonda dijital oyun oynama süresinin ise kadınların bağımlıık eğilimini artırdığı belirlenmiştir. Dijital oyun tercihleri durağan olmayıp ekonomik, sosyal ve kültürel öğelerden de etkilenmektedir. Mclnroy ve Mishna'nın (24) yaptıkları çalışma sonucunun da, görüldüğü gibi erkek öğrencilerin kız öğrencilere göre daha fazla oranda bilgisayara sahip olması, bilgisayar oyunlarının daha eskilere dayanması, bilgisayar ekranlarının daha büyük olması ve bilgisayar oyunlarının daha çekici olması erkek çocuklarının telefonun yanısıra oyunlarda bilgisayarı da tercih etmesinin nedeni olabilir. Erkek öğrencilerin dikkat ve beceri gerektiren, kişide güç gösterisi ve başarmışlık hissine sebebiyet veren savaş ve strateji oyunlarını daha çok tercih etmeleri onlara toplum tarafından da atfedilen rekabet, üstünlük, güç gösterisi ve başarmışlık hissine kızlara göre daha fazla önem vermeleriyle açıklanabilir. Literatürde bazı çalışma sonuçları da $(21,24,25)$ bulgularımızla paralel olarak kızların erkek çocuklarına göre daha az sürelerde oyun oynadığını göstermektedir. Ayrıca, erkeklerin santral sinir sisteminde oyun bağımlığı ile ilgili mekanizmalarda kadınlardan önemli farkları olduğu, beyinlerindeki memnuniyet bölgesinin daha fazla aktif durumda olduğu, bu nedenle bağımlılık yapıcı maddelerden ve davranışlardan daha fazla keyif aldıkları ve daha fazla süre geçirdikleri de $(26,27)$ gösterilmiştir.

Çalışmamızın sonuçlarına göre bağımlılık yapıcı bir alışkanlığı olanların dijital olarak en çok savaş ve strateji (\%38.9) oyunlarını tercih ettikleri, 4 saatten fazla (\%27.8) oynadıkları, COVID-19 pandemisinde oynama sürelerinde artış (\%58.4) yönünde değişim olduğunu belirttikleri görüldü. Savaş ve strateji oyunlarının özellikle çevirim içi oynanan, devamlılık gerektiren ve sıklıkla ödül sistemi tarafından desteklenen oyunlar olması nedeniyle bağımlıık yapıcı alışkanlığı olanlar tarafından daha fazla oynanması beklenen bir sonuçtur. Bağımlıık yapıcı bir alışkanlığı olan bireyler dopamin artışı nedeniyle daha fazla güç gösterisi, başarmışlık hissine neden olacağı ve haz-ödül alma duygusunu hissetmek için savaş ve strateji oyunlarını tercih ediyor olabilir. Lemmens ve Hendriks'in (28) çalışmasında, sorunlu oyun kullanıcılarının en fazla savaş ve silahlı oyunları tercih ettiği belirlenmiştir. Eichenbaum ve arkadaşları (29) da strateji oyunu oynamanın patolojik oyun oynama yatkınığını arttırdığını vurgulamaktadır. Bağımlııklara neden olan mekanizmalar benzerdir, bağımlılık yapıcı bir alışkanlık diğer bağımlılık yapıcı maddelerin kullanımında ya da davranışlarında da arttııcı etki gösterir (30). Koç'un çalışmasında sigara ve alkol bağımlılı̆ı riski olan üniversite öğrencilerinde dijital oyun bağımlılığı daha fazla görülmektedir (20). Savcı ve Aysan'a göre ise internet bağımlılığı diğer davranışsal bağımlııklar (sosyal medya, dijital oyun vb.) için bir yordayıcı olarak tanımlanır ve diğer davranışsal bağımlılıkların temelini oluşturur (31). COVID-19 salgını, küresel olarak normal aktiviteleri önemli ölçüde bozmuş olup, bu dönemde evde kalma zorunlulukları ve karantinalar, özellikle çevrimiçi oyunlar olmak üzere dijital eğlence tüketimini artırmıştır $(9,32)$. Oyun oynamak sağıklı bir başa çıkma stratejisi olsa da, bazı savunmasız bireyler için riskler oluşturabilir. Uzun süren sosyal izolasyon ve teknoloji temelli faaliyet dönemleri, sağlıksız yaşam tarzı kalıplarını sağlamlaştırma tehlikesi doğurur ve COVID-19 krizi geçtiğinde yeniden uyum sağlamada zorluklara yol açar $(9,13)$.

Çalışmamızın sonuçlarına göre evlerinde internet bağlantısı olmayanların oyun için en çok telefonu (\%98.7), internet bağlantısı olanların ise savaş ve strateji oyunlarını (\%30.5) daha sık tercih ettiği ve oyun oynama sürelerinin daha fazla olduğu görüldü. Bilgisayar ekranlarının daha büyük olması ve bilgisayar oyunlarının daha çekici olması internet bağlantısı bulunanların bilgisayar ve oyun konsolunu da tercih etmelerine neden olabilir. Savaş ve strateji oyunları çevirim içi oynanan ve devam gerektiren oyunlar olduğu için genellikle internet bağlantısının daha uzun süreli ve kısıt getirmeyen ortamlarında oynanmaktadır. Evlerinde internet bağlantısı olanların oyun sürelerinin daha fazla görülmesi Koç'un sonucu ile uyumlu iken (20), Aktaş (33) ve Balıkçı'nın çalışmasında (34) evde internet bulunmasının bu durumu etkilemediği belirlenmiştir. COVID-19 pandemisinde dijital oyun kullanımının daha fazla artmasının sebebi evinde interneti olanların interneti olmayanlara göre dijital oyunlarla daha fazla zaman geçirmeleri, internete rahat ulaşım ve ekonomik nedenler olabilir.

Öğrencilerin COVID-19 pandemi öncesi ve pandemi sürecinde dijital oyun oynama sürelerinin karşılaştırımasına bakıldığında pandemi sürecinde dijital oyunlarla geçirilen zamanda istatistiksel olarak anlamlı farklılık yaratacak şekilde artma olduğu görüldü ( $t=6.098 ; p<0.001)$. Bu bulgu literatürdeki bazı çalışma sonuçları ile uyumludur $(7,9,14,16,35)$. We Are Social ve Hootsuit'in ortak yayınladığı Nisan 2020 Dijital Raporuna göre de COVID-19 salgınında bilgisayar veya video oyunları oynamak için \% 35 daha 
fazla zaman harcanmaktadır (14). Bu bulgu pandemi sürecinde evlerinde izole olan bireylerin boş zaman aktivitelerinin az olması ve boş zamanlarda dijital oyunları özellikle stresle baş etmede bir aracı olarak kullanmaları ile açıklanabilir. Aynı zamanda gençler yoğun ve sıkıcı ders ortamından uzaklaşmak, arkadaş ortamında saygın bir yer edinmek ve sosyal kabul görme amacıyla dijital oyun oynayabilir. İnternetten dijital oyun oynamak oyuncuların diğer oyuncularla iletişim kurmasına, boş zaman değerlendirilmesine imkân verir, bilgi ve eğlence arayışlarının da ortadan kaldııımasını sağlar (36). Ayrıca DSÖ tarafından pandemi döneminde dijital oyunların rahatlamanın bir yolu olabileceği açıklaması (15) da dijital oyun kullanım süresini artırmış olabilir.

Çalışmamızın kısıtlı yönleri erkek katılımcı sayısının az olması, bu bulguların çalışmaya katılanlarla sınılı olup genellenememesi ve konu ile yapıımış çalışmaların yetersiz olmasıdır. Çalışmamızın güççü yönleri ise örneklem sayısının üzerinde öğrenciye ulaşılması ve COVID-19 pandemisinde dijital oyun bağımlılığını ele alan sınırlı sayıda çalışmadan biri olmasıdır.

Sonuç olarak; çalışmamızda pandemi sürecinde öğrencilerin \% 6.3'ü bağımlı grupta ve \% 1.6'sı yüksek düzeyde bağımlı grupta olduğu, pandemi sürecinde en çok telefonla dijital oyun oynandığı ve pandemi sürecinin dijital oyun oynama süresini, savaş-strateji oyunlarını oynama oranını arttırdığı belirlenmiştir. Çalışmamızın sonuçları doğrultusunda pandemi sürecinde kullanımı oldukça artan dijital oyunların kullanımına sınırlamalar getirilmesi, evde kalınan süre içinde dijital oyunlara alternatif yeni etkinliklerin planlanması, uzun süren sosyal izolasyon dönemlerinde aile bireyleri ve diğer arkadaş gruplarılyla mümkün olduğu ölçüde sosyal etkileşimin sürdürülmesi ve dijital oyun kullanımının bağımlılık seviyesine erişmesini önlemek için gerektiğinde ruhsal destek ve kontrol programlarının yaygınlaştıııması önerilebilir.

\section{Kaynaklar}

1. Singhal T. A review of coronavirus disease-2019 (COVID-19). Indian J Pediatr 2020; 87: 281-286.

2. Andrews JL, Foulkes L, Blakemore SJ. Peer influence in adolescence: Public-health implications for COVID-19. Trends Cogn Sci 2020; 24(8): 585-587.

3. T.C. Sağlık Bakanlığı Halk Sağlığı Genel Müdürlüğü. COVID-19 (Sars-Cov-2 Enfeksiyonu) Genel Bilgiler, Epidemioloji ve Tanı. Ankara: Sağlık Bakanlığı, 2020.

4. Rundle AG, Park Y, Herbstman JB, et al. COVID-19 related school closings and risk of weight gain among children. Obesity 2020; 28(6): 1008-1009.

5. Golberstein E, Wen H, Miller BF. Coronavirus disease 2019 (COVID-19) and mental health for children and adolescents. JAMA Pediatr 2020; 174(9): 819-820.

6. Ornell F, Schuch JB, Sordi A0, Kessler FHP. "Pandemic fear" and COVID-19: mental health burden and strategies. Braz J Psychiatry 2020; 42(3): 232-235.

7. Marsden J, Darke S, Hall W, et al. Mitigating and learning from the impact of COVID-19 infection on addictive disorders. Addiction 2020; 115: 1007-1010.

8. Kırık AM, Özkoçak V. Yeni dünya düzeni bağlamında sosyal medya ve yeni koronavirüs (COVID-19) pandemisi. Akademik Sosyal Araştırmalar Dergisi 2020; 7: 133-154.

9. King DL, Delfabbro PH, Billieux J, Potenza MN. Problematic online gaming and the COVID-19 pandemic. J Behav Addict 2020; 9(2): 184-186.

10. Irmak AY, Erdoğan S. Ergen ve genç erişkinlerde dijital oyun bağımlılı̆ı: Güncel bir bakış. Turk Psikiyatri Derg 2016; 27(2): 128-137.

11. Mustafaoğlu R, Yasacı Z. Dijital oyun oynamanın çocukların ruhsal ve fiziksel sağlığı üzerine olumsuz etkileri. Bağımlılık Dergisi 2018; 19(3): 51-58.

12. Tarhan N. Beyin ve bağımllık. Psikohayat 2016; 7: 16-20.

13. Király 0, Potenza MN, Stein DJ, et al. Preventing problematic internet use during the COVID-19 pandemic: Consensus guidance. Compr Psychiatry 2020; 100: e152180.

14. wearesocial.com. Digital in 2020 global overview. https://wearesocial.com/blog/2020/04/digital-around-theworld-in-april-2020. (21 Mayıs 2020' de ulaşıldı).

15. WHO 2020. Looking after our mental health. https://www.who.int/campaigns/connecting-the-world-to-combatcoronavirus/healthyathome/healthyathome---mental-health. (21 Mayıs 2020' de ulaşıldı). 
16. Kovid-19 sürecinde bireylerin dijital yaşamı incelendi. https://www.hurriyet.com.tr/teknoloj//kovid-19-surecindebireylerin-dijital-yasami-incelendi-41517378. (23 Mayıs 2020'de ulaşıldı).

17. Hazar E, Hazar Z. Üniversite öğrencileri için Dijital Oyun Bağımlıı̆ı Ölıçeği (Uyarlama çalışması). Spor Bilimleri Araşııımaları Dergisi 2019; 4: 308-322.

18. Esin N. Örnekleme. Erdoğan S, Nahçıvan N, Esin N.(editors). Hemşirelikte Araştırma -Süreç, uygulama, kritik. İstanbul: Nobel Tip Kitapevleri, 2017: 167-192.

19. Bülbül H, Tunç T, Aydil F. Üniversite öğrencilerinde oyun bağımlılığı: Kişisel özellikler ve başarı ile ilişkisi. Ömer Halisdemir Üniversitesi İktisadi ve İdari Bilimler Fakültesi Dergisi 2018; 11: 97-111.

20. Koç AK. Lise ve üniversite öğrencilerinde internet oyun bağımlılı̆ı sıklğı ve etkili faktörler. Uzmanlık Tezi, Ankara: Gazi Üniversitesi Tıp Fakültesi, Halk Sağlığı Anabilim Dalı, 2020.

21. Miezaha D, Batchelora J, Megreyab AM, et al. Video/computer game addiction among university students in ghana: Prevalence, correlates and effects of some demographic factors. Psychiatry and Clinical Psychopharmacology 2020; 30(1): 17-23.

22. Li H, Zou Y, Wang J, Yang X. Role of stressful life events, avoidant coping styles, and neuroticism in online game addiction among college students: A moderated mediation model. Front Psychol 2016; 7: 1794.

23. Lee C, Kim 0. Predictors of online game addiction among Korean adolescents. Addict Res Theory 2017; 25(1): 58-66.

24. Mclnroy LB, Mishna F. Cyberbullying on online gaming platforms for children and youth. Child Adolesc Social Work J 2017; 34(6): 597- 607.

25. Korkmaz Ö, Korkmaz Ö. Ortaokul öğrencilerinin oyun bağımlılık düzeyleri, oyun alışkanlıkları ve tercihleri. İnönü Üniversitesi Eğitim Fakültesi Dergisi 2019; 20: 798-812.

26. Becker JB, McClellan ML, Reed BG. Sex differences, gender and addiction. J Neurosci Res 2017; 95(1-2): 136-147.

27. Dong G, Zheng H, Liu X, et al. Gender-related differences in cue-elicited cravings in Internet gaming disorder: The effects of deprivation. J Behav Addict 2018; 7(4): 953-964.

28. Lemmens JS, Hendriks SJ. Addictive online games: Examining the relationship between game genres and Internet gaming disorder. Cyberpsychol Behav Soc Netw 2016; 19(4): 270-276.

29. Eichenbaum $A$, Kattner $F$, Bradford $D$, et al. Role-playing and real-time strategy games associated with greater probability of internet gaming disorder. Cyberpsychol Behav Soc Netw 2015; 18(8): 480-485.

30. Arıkan Z. Çoklu Madde Kullanımı. T.C. Sağlık Bakanlığı Sağlık Hizmetleri Genel Müdürlüğü. Madde bağımlı̆̆g tanı ve tedavi kılavuzu el kitabı. Ankara: Pozitif Matbaa, 2012; 207-210.

31. Savcı M, Aysan F. Teknolojik bağımlılıklar ve sosyal bağlıık: internet bağımlıı̆̆ı, sosyal medya bağımlıı̆ı, dijital oyun bağımlılığı ve akıllı telefon bağımllığının sosyal bağlıı̆ı yordayıcı etkisi. Dusunen Adam 2017; 30: 202216.

32. Javed J. eSports and gaming industry thriving as video games provide escape from reality during coronavirus pandemic. https://www.wfaa.com/article/sports/esports-gaming-industry-thriving-as-video-games-provideescape-from-reality-during-coronavirus-pandemic/287-5953d982-d240-4e2b-a2ba-94dd60a8a383.

Kasım 2020' de ulaşıldı).

33. Aktaş B. Ortaokul öğrencilerinde internet ve dijital oyun bağımlıı̆ının psikolojik sağlamlık ve saldırganlıkla ilişkisi. Yüksek Lisans Tezi, Kars: Kafkas Üniversitesi, Hemşirelik Anabilim Dalı, 2018.

34. Balıkçı R. Çocuklarda ve ergenlerde çevrimiçi oyun bağımlılı̆ı ve agresif davranışlar arasındaki ilişkinin incelenmesi. Yüksek Lisans Tezi, İstanbul: Fatih Sultan Mehmet Vakıf Üniversitesi, Psikoloji Anabilim Dalı, 2018.

35. Balhara YPS, Kattula D, Singh S, et al. Impact of lockdown following COVID-19 on the gaming behavior of college students. Indian J Public Health 2020; 64(6): 172-176.

36. Tran GA, Strutton D. What factors affect consumer acceptance of in-game adversitements? Click "like" to manage digital content for players. J Advert Res 2013; 53(4): 455-469. 